Psychológia a patopsychológia

dietała, 53, 2019, č. 1, s. 5-24.

\title{
SKÚSENOSTI MATIEK S VÝCHOVOU DETÍ S ADHD - FENOMENOLOGICKÁ ANALÝZA
}

\author{
MONIKA BÚRANOVÁ - JANA VINDIŠOVÁ \\ Katedra psychológie FFTU v Trnave, Centrum pre deti a rodinu, \\ Sered
}

\author{
MOTHERS' EXPERIENCES OF RAISING A CHILD WITH \\ ADHD - PHENOMENOLOGICAL ANALYSIS
}

\begin{abstract}
The aim of this study was to provide a deeper insight into the experience of mothers raising a child with ADHD. Four semi-structured in-depth interviews were conducted and subsequently analysed and interpreted using Interpretative Phenomenological Analysis, which led to identification of three basic thematic areas: Specific Experiences of Mothers with ADHD Child, Characteristics of Assistance and Support, Maternal Reflection of Experience with ADHD. The results indicate that when raising a child with ADHD, mothers experienced lack of understanding and acceptation from the school and its change was considered as the only solution. The intervention program for families with ADHD was found very effective and useful, and despite of many parental difficulties, mothers were able to see positive aspects of the situation leading to their personal growth.
\end{abstract}

Key words: maternity, intervention program, personal growth, phenomenological analysis

Porucha pozornosti a hyperaktivity (ADHD) je v súčasnosti jednou z najčastejších a najviac skúmaných detských porúch. Svedčí o tom množstvo štúdií a odborných kníh publikovaných na danú tému. ADHD možno definovat ako skupinu prevažne geneticky podmienených neurobiologických dysfunkcií, ktoré znižujú schopnosỉ detí zamerat a udržat pozornost', prispôsobovat aktivitu požiadavkám okolia a ovládat svoje impulzy. Deficity sa manifestujú v troch základných kategóriách príznakov:

Prišlo 18. 3. 2019. J. V., FFTU, Hornopotočná 23, 91843 Trnava

E-mail: jankavindisova@gmail.com

DOI: $10.4149 /$ ppd_201901 
nepozornosé, hyperaktivita a impulzivita (Uhlíková et al., 2014). Podla výskumných zistení je ADHD celosvetovo najrozšírenejšou poruchou v školskom veku (Polanczyk et al., 2014; Sonuga-Barke et al., 2010). Pritom sa širokospektrálne dotýka rodiny, školy i vol’nočasových aktivít (Kvašná, 2011). Napriek tomu bola skúsenostiam rodičov detí s ADHD venovaná podstatne menšia pozornoste. Podla Craiga et al. (2016) sú rodiny s takýmito dęmi vystavené vyššiemu riziku konfliktov, rozpadu manželstva, zníženej rodičovskej sebaúcty a sociálnej izolácie. Zistenia by mali byt doplnené o hlbšie poznanie ludskej skúsenosti, čo možno realizovat pomocou metód kvalitatívneho výskumu. Cielom predkladanej štúdie je prostredníctvom fenomenologickej analýzy poskytnút hlbšie porozumenie skúsenostiam matiek, ktoré vychovávajú dieła s diagnózou ADHD.

Vztahy v rodine s diełałom s ADHD sú charakteristické neustálym napätím, vyplývajúcim najmä zo silne opozičného správania detí (Laver-Bradbury, 2013). Ich reakcie v konfrontácii s rodičmi a súrodencami bývajú unáhlené, bez zváženia dôsledkov konania. Pretože ide o behaviorálnu poruchu spojenú so zhoršením samoregulácie, sociálne interakcie detí a adolescentov sú neprimerané, rušivé, intenzívne a agresívne (Kendall et al., 2005). Metaanalýza kvalitatívnych výskumov (Corcoran et al., 2017) poukazuje predovšetkým na silnú emocionálnu zátaž rodičov pri starostlivosti o dieła s ADHD. Potvrdilo sa tiež, že rodičia neraz bojujú s intenzívnymi a bolestivými emóciami pri snahe zvládat rutinné povinnosti, čo sa premieta aj do iných oblastí života, ako je ich zdravotné, psychologické, manželské a pracovné fungovanie (Corcoran et al., 2017). Problémy sa zvýrazňujú po dosiahnutí školského veku (Laver-Bradbury, 2013). Emočná zátaž, spojená s výchovou diełała $\mathrm{s}$ ADHD, súvisí so zvýšenou mierou rodičovského stresu (napr. Lange et al., 2005; Yousefia et al., 2011; Finzi-Dottan et al., 2011). Pri porovnaní miery stresu sa ukázalo, že hoci vyššie opísané problémy zasahujú oboch rodičov, vyššia úroveň subjektívneho utrpenia bola pozorovaná u matiek (Kendall et al., 2005). Miera stresu tiež závisí od závažnosti príznakov poruchy (Yousefia et al., 2011).

$\mathrm{Na}$ atmosféru v rodine s dietafom s ADHD okrem spomenutých psychosociálnych faktorov môže negatívne pôsobił aj odmietanie okolia. Spätná väzba zo školského prostredia býva $\mathrm{v}$ tejto oblasti klúčová. Rodičia musia bojovat' $\mathrm{s}$ nepriazňou zo strany učitelov, ked’ často čelia obvineniam z nesprávnej výchovy (Minaříková, 2010), ale aj odmietaniu diełała zo strany rovesníkov a ich rodičov (Laver-Bradbury, 2013). To prirodzene vedie $\mathrm{k}$ pocitom demotivácie, frustrácie a nedôvery vo vlastné rodičovské kompetencie (Corcoran et al. 2017). Na druhej strane treba poznamenat, že niekedy samotní rodičia majú problém prijat skutočnosté, že ich dieta má psychickú poruchu a je potrebné pri výchove spolupracovat s odborníkmi (Minaříková, 2010). 


\section{Intervencie pre rodiny s detmi s ADHD na Slovensku}

Deti s ADHD tvoria početnú klientelu centier pedagogicko-psychologického poradenstva a prevencie. Podla Z. Hlaváčovej (2015) sa na terapii ADHD podielajú najčastejšie psychológ, špeciálny pedagóg, prípadne pedopsychiater a neurológ, v ideálnom prípade tiež psychoterapeut, sociálny pracovník či rodinný terapeut. Podporné skupiny, ktoré združujú rodičov detí, sú podla L. Kvašnej (2011) vel’mi vhodnou možnostou sociálnej podpory pre rodičov, na Slovensku však zatial' nie sú dostatočne rozšírené. Rodičom ponúkajú vzájomnú oporu, uvol’nenie emočného napätia, spätnú väzbu, skupinovú dynamiku a učenie sa zdielaním vzájomných skúseností (Kalina, podla Hlaváčovej, 2015). V zahraničí patria k dominantným formám poskytovania sociálnej pomoci. S. Rief považuje podporné rodičovské skupiny za jednu z najúčinnejších metód v terapii ADHD (Hlaváčová, 2015).

K rozsiahlym a prepracovaným intervenčným programom na Slovensku patrí projekt Rodina s hyperaktívnym dietatom, ktorý od roku 2009 realizuje mimovládna organizácia Detský fond SR. Jeho súčastou je: a) psychologické poradenstvo rodičom, b) terapeutické a poradenské skupiny pre rodičov s detmi, zamerané na rozvoj rodičovských zručností s možnostou výmeny skúseností, c) pobytové aktivity pre rodiny. Cielom pobytov, situovaných v prírodnom prostredí, je na základe spoločných zážitkov lepšie spoznat potreby jednotlivých členov, rozvoj vztahov a zlepšenie komunikácie v rodine. Na projekte participujú niekol'kí psychológovia a špeciálny pedagóg. Nevýhodou je lokalizácia aktivít $\mathrm{v}$ hlavnom meste, a tým obmedzený prístup rodičov z iných oblastí (pozri aj Štepita, 2014).

Podobným projektom, ktorý bol podrobnejšie zmapovaný vo výskume Z. Hlaváčovej (2015), je podporná skupina rodičov detí s ADHD v Nitre, fungujúca od roku 2014. Edukačná časî projektu obsahuje vopred špecifikovanú tému z okruhu ADHD s aktivitami zážitkového charakteru a interaktívnymi prvkami. Súčastou stretnutí sú diskusie o nastolených problémoch, ktoré môžu mat sekundárny terapeutický efekt. Situácia v oblasti psychosociálnej terapie ADHD na Slovensku nie je centralizovaná, ide skôr o ojedinelé projekty, bez vzájomnej spolupráce medzi sebou (Štepita, 2014).

\section{Fenomenologická analýza rozhovorov s matkami detí s ADHD}

Pre naše výskumné zámery bola zvolená kvalitatívna metódu s názvom Interpretatívna fenomenologická analýza (d’alej len IPA). Ide o prístup, ktorý vychádza z fenomenológie, hermeneutiky a ideografie. Cielom je detailne preskúmat individuálnu skúsenosî respondenta a zistit, aký význam a zmysel jej pripisuje (Smith, Flowers, Larkin, 2009). Nepokúša sa o objektívny opis objektu alebo udalosti samotnej, skôr sa na základe dynamického procesu výskumu snaží čo najviac priblížit osobnému 
svetu prostredníctvom aktívneho vstupu výskumníka s jeho vlastnými koncepciami, ktoré sú potrebné na jeho uchopenie problému cez proces interpretácie. Skúsenosi je teda prostredníctvom tejto metódy konštruovaná ako produkt spoločného zdielania skúmajúceho a respondenta (Smith, Eatough, 2011). J. Kostínková a I. Čermák (2013) metódu považujú za vhodnú pre začiatočníkov v kvalitatívnom výskume, pretože ponúka dostatok priestoru na kreativitu a slobodu výskumníka, no proces spracovania dát je dostatočne štruktúrovaný a jednoznačný.

\section{Ciel' výskumu a výskumná otázka}

Cielom štúdie bolo zamerâ sa na hlbšie porozumenie skúsenostiam matiek, ktoré vychovávajú dieta s diagnózou ADHD, pričom sme chceli poukázat na subjektívne najvýraznejšie problémy, ktorým musia čelit pri výchove hyperaktívneho dietała, ako aj na ich prežívanie a techniky zvládania, ktoré používajú pri prekonávaní týchto problémov. D̃alším cielom bolo identifikovat klúčové potreby matiek detí s ADHD a prostredníctvom materskej reflexie poukázat na prínosy a negatíva prežitých skúseností. Na základe týchto cielov a vychádzajúc z odporúčaní metódy IPA (Smith, Osborn, 2003) sme stanovili otvorenú, fenomenologicky zameranú výskumnú otázku: Aká je skúsenosí matiek pri výchove detí s ADHD?

\section{Výskumný súbor}

Pre potreby výskumu sme zvolili zámerný výber matiek, ktoré dobre reprezentujú skúmaný fenomén. Zástancovia IPA uprednostňujú bohatosi a híbku informácií pred kvantitou účastníkov, preto odporúčajú zahrnút menší počet a v prípade pilotných prác odporúčajú rozsah 3 až 6 respondentov (Smith, Flowers, Larkin, 2009). Z toho dôvodu boli do výskumu zaradené štyri ženy, ktoré spĺňali hlavné kritérium - materstvo dietała s diagnostikovanou poruchou ADHD. Vek detí bol v rozmedzí od 9 do 16 rokov. Respondentky boli oslovené priamo, i cez sociálne siete (bližšie údaje o matkách a detoch pozri v tabul'ke 1). Mená boli kvôli zabezpečeniu anonymity zmenené.

Matky zhodne uvádzajú výskyt príznakov už v predškolskom veku diełała, avšak vo všetkých prípadoch bola diagnóza ADHD stanovená psychológom alebo psychiatrom po zahájení školskej dochádzky a stupňujúcich sa problémoch v učení. Pomoc psychológa, prípadne špeciálneho pedagóga vyhladali všetky matky najmä v súvislosti so školským procesom, medikamentózna liečba bola napriek odporúčaniam nasadená len u dvoch detí (syn Diany a dcéra Evy).

\section{Štruktúra a realizácia rozhovorov}

Zber dát bol uskutočnený v mesiacoch november 2017 až január 2018 prostredníctvom pološtruktúrovaného rozhovoru s otvorenými otázkami, ktorý je v IPA po- 


\section{Údaje o účastníčkach výskumu}

\begin{tabular}{|l|c|c|c|c|}
\hline Matky: & Anna & Beáta & Diana & Eva \\
\hline Vek matky v rokoch & 43 & 39 & 37 & 44 \\
\hline Vzdelanie & SŠ & VŠ & SŠ & SŠ \\
\hline Rodinný stav & vydatá & vydatá & slobodná & rozvedená \\
\hline Domácnosł & s manželom & s manželom & s partnerom & s partnerom \\
\hline Pohlavie a vek diełała s ADHD & dcéra $(11 \mathrm{r})$. & syn $(9 \mathrm{r}$.) & syn $(15$ r.) & dcéra $(16$ r.) \\
\hline Počet súrodencov dietata & 1 & 1 & - & - \\
\hline
\end{tabular}

Pozn.: "Biologický otec nežije v spoločnej domácnosti

važovaný za najvhodnejšiu metódu zberu údajov, pretože ponúka dostatok priestoru na vyjadrenie a rozvíjanie vlastných myšlienok k téme (Smith, Eatough, 2011). Miesto rozhovoru si vyberali účastníčky a individuálne rozhovory trvali približne 60 - 90 minút. Každý rozhovor bol s informovaným súhlasom matiek nahrávaný na diktafón a následne doslovne prepísaný. Prvá časê otvorených otázok sa týkala minulých skúseností s výchovou diełała pred a po diagnostikovaní ADHD. V druhej časti sa otázky týkali matkinho prežívania, zvládania a vnímania pomoci od okolia. Na záver sme ponúkli respondentkám priestor na dodatočné doplnenie svojich myšlienok $\mathrm{k}$ téme prostredníctvom emailu alebo telefonicky. Ponuku využili všetky respondentky a ich doplňujúce informácie sme následne prepísali a priradili k rozhovorom.

\section{Analýza rozhovorov}

Analýza rozhovorov bola realizovaná podla odporúčaní pre IPA, ktoré opísali Smith, Flowers a Larkin (2009): (1) čítanie a opakované čítanie, (2) počiatočné poznámky a komentáre, (3) rozvíjanie vznikajúcich tém, (4) hladanie súvislostí medzi témami, (5) analýza d’alšieho prípadu, (6) hladanie vzorcov naprieč prípadmi. Komentáre výskumníka môžu vychádzạ zo sémantického obsahu, jazyka, z podobností a rozdielov, môžu byt sumarizáciou, parafrázou a niektoré z nich sa stanú zárodkami budúcich interpretácií (Smith, Osborn, 2003). Komplexné a detailné poznámky $\mathrm{k}$ dátam majú deskriptívnu povahu, a sú tak v súlade s fenomenologickým postojom, ktorého základom je blízkost k respondentovmu videniu sveta (Kostínková, Čermák, 2013). Cielom tretej fázy je redukcia dát na tie, ktoré pomáhajú rozvíją komentáre a prispievajú k vytvoreniu tzv. rodiacich sa tém, zachytávajúcich esenciálnu kvalitu skúsenosti. V d’alšej fáze sú odhalované vnútorné vztahy medzi témami, výsledkom čoho je zoznam hlavných tém so subtémami. Následne sa pristupuje k analýze d’alších rozhovorov. 
Analýza dát bola realizovaná manuálne, bez použitia štatistického softvéru, na základe opätovného čítania, interpretovania, analýzy a syntézy rozstrihaných prepisov rozhovorov za účelom logickej štruktúry. Pre overenie dôveryhodnosti interpretácií boli tieto konzultované s nezávislou analyzátorkou, ktorá mala skúsenosti s využitím metódy IPA v psychologickom výskume. Analýza jednotlivých rozhovorov bola zavŕšená celkovou analýzou, ktorá spočívala v hladaní súvislostí medzi prípadmi. Témy boli postupne rozdelované do skupín podla vzájomných vztahov. Vytvoreným skupinám boli následne pridelené abstraktnejšie názvy. Finálnym krokom bolo vytvorenie tabul'ky so zoznamom oblastí, ktoré obsahujú skupiny hlavných tém a vynorených subtém. Tento krok bol opätovne verifikovaný viacerými analyzátorkami a následne upravený podla relevantných pripomienok. Ako uvádzajú J. Smith et al. (2009), zapojenie viacerých výskumníkov zabezpečuje dôveryhodnosî interpretácie, nejde však o jediný spôsob, ako sa k nej dopracovat. Z pohladu IPA je kvalitná interpretácia, ktorá je založená najmä na výpovediach respondenta a je podložená jeho priamymi citáciami.

\section{Výsledky fenomenologickej analýzy}

Pri analýze výpovedí o subjektívnej skúsenosti participantiek sme dospeli k sformulovaniu troch hlavných oblastí: a) Špecifiká materstva s diełałom s ADHD, b) Charakteristika pomoci a podpory a c) Materská reflexia skúseností s ADHD. V rámci uvedených oblastí boli sformulované hlavné témy a subtémy a následne bol zistovaný ich výskyt $v$ jednotlivých výpovediach.

\section{a) Špecifiká materstva s dietatom s ADHD}

V rámci tejto oblasti boli formulované štyri hlavné témy so subtémami, ktorých výskyt je prehladne zaznamenaný v tabulke 2 .

\section{Diagnostika ADHD:}

Z rozhovorov vyplynulo, že pred stanovením diagnózy prechádzali matky so svojimi deţmi turbulentným obdobím od uvedomenia si zvláštností v správaní diełała až po riešenie problémov v materskej škole (MŠ). Každá z matiek ešte pred nástupom do školy tušila, že jej dieta je hyperaktívne, či už vd’aka návšteve psychológa, alebo z náznakov učiteliek v MŠ, avšak s diagnostikou počkali až do času stupňujúcich sa problémov diefata v škole a učinili tak na podnet učitelov.

Zaznamenanie prvých príznakov - všetky participantky si spätne uvedomili, že už od útleho veku dietata si všimli indície vztahujúce sa k ADHD, avšak ešte netušili, že môže íst o nejakú poruchu. Každá z matiek zdôrazňuje iný príznak, avšak všetky sa zhodujú v tom, že evidovali rozdiely v správaní oproti iným detom. Beáta spomína: 
Témy a subtémy tematickej oblasti Špecifiká materstva dietata s ADHD

\begin{tabular}{|c|c|c|c|c|c|}
\hline \multirow{2}{*}{ Témy } & \multirow{2}{*}{ Subtémy } & \multicolumn{4}{|c|}{ Participantky - matky } \\
\hline & & Anna & Beáta & Diana & Eva \\
\hline \multirow{3}{*}{$\begin{array}{l}\text { Diagnostika } \\
\text { ADHD }\end{array}$} & Zaznamenanie prvých príznakov & $*$ & $*$ & $*$ & $*$ \\
\hline & Riešenie prvotných problémov & $*$ & $*$ & $*$ & $*$ \\
\hline & Reakcie po stanovení diagnózy & $*$ & $*$ & $*$ & * \\
\hline \multirow{6}{*}{$\begin{array}{l}\text { Školské } \\
\text { problémy }\end{array}$} & Najvýraznejšie problémy dietata & $*$ & $*$ & $*$ & $*$ \\
\hline & Príprava do školy & $*$ & $*$ & $*$ & $*$ \\
\hline & Neakceptácia poruchy & $*$ & $*$ & $*$ & $*$ \\
\hline & Rozhovory s učitel'mi & $*$ & $*$ & $*$ & $*$ \\
\hline & $\begin{array}{l}\text { Pokarhanie - trest pre dieta či pre } \\
\text { rodiča? }\end{array}$ & $*$ & $*$ & $*$ & \\
\hline & $\begin{array}{l}\text { Zmena školy ako jediné } \\
\text { východisko }\end{array}$ & $*$ & $*$ & $*$ & $*$ \\
\hline \multirow{3}{*}{$\begin{array}{l}\text { Prežívanie } \\
\text { a zvládanie }\end{array}$} & Pretaženost' matiek & $*$ & $*$ & $*$ & $*$ \\
\hline & Pocity nezvládania a zúfalstva & $*$ & $*$ & $*$ & $*$ \\
\hline & Zdroje pre zvládanie & $*$ & $*$ & $*$ & $*$ \\
\hline \multirow{4}{*}{$\begin{array}{c}\text { Vztah matka } \\
\text { - dieta }\end{array}$} & Vnímanie dietata z pohladu matky & $*$ & $*$ & & * \\
\hline & Nepochopenie dietata & & $*$ & $*$ & $*$ \\
\hline & Ambivalencia emócií & $*$ & $*$ & * & * \\
\hline & Potreba porozumiet dietatu & & $*$ & $*$ & $*$ \\
\hline
\end{tabular}

„Užjak bol malinký, tak som videla, že je dost také nepokojné dietatko. To som ešte nejak nebrala, len od chvíle, ked'sa začal hýbat', tak sa hýbal v kuse."

Riešenie prvých problémov s dietatom - prvé vážnejšie problémy v správaní zaznamenali matky po nástupe do MŠ, kde ich na ne začali upozorňovat aj učitelky. Beáta hovorí: „....tak sa nás aj učitelka v škôlke spýtala, že a to vy ho v noci nabijate na 220? " Matky na upozornenia niekedy reagovali obranným postojom, prípadne zmenou škôlky, jediná matka sa rozhodla navštívit odborníka.

Reakcia po stanovení diagnózy - všetky matky navštívili psychológa kvôli stanoveniu diagnózy diełała vo veku od 6 do 8 rokov. V tom čase už predpokladali, že ich dieta má nejaký problém a diagnóza ADHD pre ne často nebola prekvapivá. Niektoré opisujú úlavu, pretože dovtedy mali pochybnosti o vlastných rodičovských kompetenciách a potvrdenie ADHD bolo povzbudením, že nie sú „neschopné matky“. 


\section{Školské problémy:}

Téma školských problémov mala najbohatšie zastúpenie v rozhovoroch so všetkými matkami, čo naznačuje, že táto oblaste im prináša najväčšie starosti. Zároveň sa prelínala s d’alšími oblastami, či už išlo o tému Prežívania a zvládania alebo Podporu od okolia. Treba tiež zdôraznit pozoruhodnú zhodu vo všetkých vynorených subtémach.

Najvýraznejšie problémy dietata $v$ škole - po nástupe diełała do školy zaznamenali matky problémy so sústredením, pracovným tempom, agresivitou, negativizmom a neustálym vyrušovaním. Diana uvádza:, ,Stále mi učitelka hlásila, že syn nepracuje, neposlúcha, vyrušuje, stále sa vrtí... takmer každý deň nosil domov poznámky. “ Vo výpovediach matiek sme zaznamenali snahu o konštruktívne riešenie problémov za pomoci odborníkov.

Príprava do školy - každá matka venovala (resp. venuje) zvýšené úsilie a čas ( 2 - 3 hodiny denne už v 1 . ročníku) domácej príprave. Beáta spomína: „,... napísat pár viet, to bolo na dve - tri hodiny. “ Matky museli zápasie nielen s časom, ale aj s motiváciou dietata učit sa. Zhoda medzi matkami bola aj v potrebe zapojit vlastnú kreativitu a vymýšlat efektívne metódy učenia. Prípravu do školy komplikovala neschopnosi detí poznačit si domácu úlohu či zapisovat poznámky. Pomoc s učením je často potrebná nielen $\mathrm{v}$ začiatkoch školskej dochádzky, ale často až do prípravy na strednú školu, prípadne aj počas nej, najmä v dôsledku deficitu exekutívnych funkcií.

Neakceptácia poruchy - z rozprávania matiek je zjavné, že ich reálna skúsenose $\mathrm{s}$ individuálnou integráciou detí a rešpektovaním súvisiacich odporúčaní nebola v zhode s ich očakávaniami; matky opisujú pocity bezmocnosti a frustrácie. Okrem toho sa museli neraz vysporiadat s psychicky náročnými až traumatizujúcimi situáciami. Anna napríklad uviedla: „Učitel’ ju priviazal $k$ stoličke $-s$ gumičkami, aby sa proste už, aby s tými nohami netrepala... Pritom mi povedal, že ona sa nebaví s detmi, ale je neposedná. “

Rozhovory s učitelmi - v súvislosti s vnímaným nepochopením zo strany učitelov sme zisłovali reakcie matiek. Vo výpovediach zaznamenávame odhodlanosî, aktivitu, snahu riešit problémy a spolupracovat s učitelmi. Viaceré verbalizovali nepríjemné pocity a bezradnosé z neustáleho vysvetlovania a doprosovania sa. Diana to opisuje: „Bol to neustály boj s učitelmi... Ked'som išla za učitelkou porozprávat'sa, vykreslila mi moje dieta ako nevychovaného netvora... Toto bolo fakt najtažšie obdobie. Chodila som do školy ako na klavír a tam mi len nakladali a nakladali." Na druhej strane matky oceňovali prejavy ústretovosti a individualizácie prístupu, pričom uvádzali pozitívne skúsenosti s konkrétnymi učitel'mi (napr. učitel'ka angličtiny Anninej dcéry).

Pokarhanie - trest pre dieła či pre rodiča? Ako významný zdroj frustrácie respondentky uvádzali časté poznámky a pokarhania detí. Subtéma je úzko prepojená z prežívaním a zvládaním, avšak pre školský kontext bola zaradená do témy Školské problémy. Vo výpovediach dominujú pocity krivdy, nepochopenia, demotivácie 
a hnevu, ktoré vyplývali z rozporu medzi úsilím matky a výsledkami, i hodnotením diełała. Anna spomína: „štve ma, ked' je poznámka, že je nepripravená, ked’viem, kolko sa ona pripravovala... oni tí učitelia nemajú predstavu o tom... “"

Zmena školy ako jediné východisko - ukazuje sa, že matky časom začínajú vnímạ zmenu školy ako jediné východisko, o čo ich neraz žiadali samotné deti. Pre radikálne riešenie sa často rozhodli po vystupňovaní spomínaných problémov. Diana s Evou realizovali zmenu školy dvakrát. Ako významný dôvod uvádzajú ,zaškatulkovanie dietata“. (Diana o synovi: „On už sa nedokázal vymanit z tej nálepky, ktorú v tej škole mal - všetky problémy robil on. ") Beáta zvolila na základe referencií súkromnú školu, napriek finančným nákladom. Pozitívne možno hodnotit zistenie, že po zmene školy boli pozorované pozitívne zmeny, vyššia spokojnost dietata, pochopenie zo strany učitelov, ako aj začlenenie dietała do kolektívu.

\section{Prežívanie a zvládanie:}

Z jednotlivých rozhovorov vyplynulo, že každodenné riešenie problémov diełała $\mathrm{v}$ škole, konflikty s učitel'mi, ako aj obavy z budúcnosti mali vel'ký vplyv na emocionálne prežívanie matiek. V tejto oblasti boli identifikované tri subtémy.

Pretaženie - v odpovediach sa často vyskytovali slová ako vyčerpanie a únava.

Pocity nezvládania a zúfalstva priznávali v rozhovoroch všetky matky. Diana spomína: „Bývala som vyčerpaná a zúfalá. Často som plakala a búchala od nervov do podušky... “ Matky pomenovávali „kritické obdobia“, kedy vnímali zvýšený stres a nároky na zvládanie - išlo najmä o dni vyučovania so zvýšenými požiadavkami na výkon, naopak ako „záchranné obdobia“ označovali predovšetkým letné prázdniny.

Zdroje energie na zvládanie - matky sa vyjadrili aj k tomu, čo im pomáha zvládat problémy spojené s výchovou dietata s ADHD. Anna považuje za cenný zdroj rodinné zázemie, ale aj prežívanú materinskú lásku k dietału. Beáta energiu čerpá v športe a záujmových aktivitách. Z rozhovorov vyplýva, že matky často pociłujú absolútny nedostatok času, ktorý by mohli venovat sebe. Anna konštatuje:,,môj život osobný je úplne mimo... neoddychujem, ani nešportujem, necvičím - riešim len ju a domácnosi"“.

\section{Vztah matka - dieta:}

Prežívanie vzájomného vzłahu bolo pre matky s hyperaktívnym diełałom citlivou témou. Je zjavné, že tažko znášajú negatívne prejavy a balansujú medzi pocitmi lásky, hnevu i sklamania. Ukázalo sa, že okrem Anny sa všetky participantky zameriavali viac na negatívne, ako na pozitívne charakteristiky diefała. $\mathrm{V}$ tomto kontexte boli v takmer všetkých rozhovoroch zaznamenané štyri subtémy - vnímanie dietata z pohladu matky, nepochopenie vlastného diełała, ambivalencia emócií a potreba porozumiet dietatu. 
Vnímanie dietaia z pohladu matky - zaznamenali sme tendenciu, že matky detí $\mathrm{s}$ ADHD prechádzajú procesom zmeny v postoji $\mathrm{k}$ nemu - od nepochopenia, cez spracovávanie negatívnych emócií, až po akceptáciu či neakceptáciu.

Nepochopenie vlastného dietata - u Anny ako jedinej z matiek sme subtému nepochopenia voči vlastnému dietatu neevidovali. Negatívnu konotáciu používala len v súvislosti so školskými tažkostami. Diana, ktorá je matkou adolescenta, priznáva, že $\mathrm{v}$ začiatkoch prechádzala obdobím nepochopenia či neporozumenia vlastnému diełatu, ,....niekedy som už nevedela, čo je ešte porucha a čo je jeho povaha, že kde je tá hranica? " Napriek lažkým obdobiam si uvedomovala, aké dôležité je vytvorie synovi bezpečné prostredie a prejavit mu lásku. Postupom času sa naučila so synom efektívnejšie pracovat a ich vztah sa zlepšoval, čo zároveň pripisuje aj jeho veku a schopnosti verbalizovat pocity. Aktuálne hodnotí vztah so synom ako pozitívny.

Potreba porozumiet dietatu - Eva uvádza, že predtým, ako začala navštevovat intervenčný program, považovala dcéru za ,zlé decko“. Až neskôr si uvedomila potrebu zmeny prístupu. S odstupom času konštatuje: „Bola som vyčerpaná, že proste vzíah sme si kazili navzájom."

\section{b) Charakteristika pomoci a podpory}

Druhú tematickú oblasi charakterizovali štyri hlavné témy, o ktorých matky rozprávali najčastejšie: Prvá pomoc odborníkov, Podpora okolia, Intervenčný program ako „bod zlomu“ a Potreby a očakávania matiek (tabul'ka 3).

Pocit nedostatku informácií od psychológov zdôrazňovali matky najmä v súvislosti s praktickými radami $\mathrm{k}$ výchove. $Z$ výpovedí Beáty a Evy vyplynulo, že po diagnostike dostali od psychológov len stručné informácie, súčasne vyjadrujú pocit, že odborníci sú dobrí len na označkovanie diełała a na predpísanie liekov: ,psychologička ti len povie, že je ADHD, pošle ta psychiatrovi a psychiater dá lieky“, hovorí Beáta. Matky zároveň uvádzajú, že potrebné odporúčania, najmä vo vztahu ku škole, im poskytli špeciálne pedagogičky.

Skúsenosti s medikáciou - o skúsenostiach s liekmi na ADHD sa zmienili viaceré matky, i ked' v skutočnosti liečbu vyskúšali len deti Diany a Evy. Napriek prvotným pozitívnym očakávaniam bol u všetkých matiek zaznamenaný skôr negatívny postoj k farmakoterapii. Diana hovorí o súhlase s liečbou „pod tlakom školy... “, čo spätne hodnotí negatívne: „mala som očakávania, že by sa mohol upokojit a menej vyrušovat, ale jeho organizmus tie lieky vôbec neprijal - mal dost' vážne vedlajšie účinky... “

\section{Podpora od okolia:}

K téme sociálnych zdrojov zvládania sa vyjadrili všetky participantky, pričom sme identifikovali dve subtémy. 
Témy a subtémy tematickej oblasti Charakteristika pomoci a podpory

\begin{tabular}{|c|c|c|c|c|c|}
\hline \multirow{2}{*}{ Témy } & \multirow{2}{*}{ Subtémy } & \multicolumn{4}{|c|}{ Participantky - matky } \\
\hline & & Anna & Beáta & Diana & Eva \\
\hline $\begin{array}{l}\text { Prvá pomoc od } \\
\text { odborníkov }\end{array}$ & $\begin{array}{l}\text { Nedostatok informácií } \\
\text { Psychológ - označkovanie, psychiater - lieky } \\
\text { Skúsenosti s medikáciou }\end{array}$ & & $*$ & $\begin{array}{l}* \\
* \\
*\end{array}$ & $\begin{array}{l}* \\
* \\
*\end{array}$ \\
\hline $\begin{array}{l}\text { Podpora od } \\
\text { okolia }\end{array}$ & $\begin{array}{l}\text { Zapojenie otca a ostatnej rodiny } \\
\text { Nedostatok podpory zo strany spoločnosti }\end{array}$ & * & * & * & * \\
\hline $\begin{array}{l}\text { Intervenčný } \\
\text { program ako } \\
\text { „bod zlomu““ }\end{array}$ & $\begin{array}{l}\text { Praktické informácie } \\
\text { Uvedomenie si potreby zmeny prístupu } \\
\text { Aplikácia nových postupov do výchovy } \\
\text { Sociálna podpora v terapeutickej skupine }\end{array}$ & & $\begin{array}{l}* \\
* \\
* \\
*\end{array}$ & $\begin{array}{l}* \\
* \\
* \\
*\end{array}$ & $\begin{array}{l}* \\
* \\
* \\
*\end{array}$ \\
\hline $\begin{array}{l}\text { Potreby } \\
\text { a očakávania } \\
\text { matiek }\end{array}$ & $\begin{array}{l}\text { Spolupráca školy } \\
\text { Asistent učitela } \\
\text { Športové krúžky } \\
\text { Osveta o ADHD }\end{array}$ & $*$ & $\begin{array}{l}* \\
* \\
* \\
*\end{array}$ & $\begin{array}{l}* \\
* \\
* \\
*\end{array}$ & $*$ \\
\hline
\end{tabular}

Zapojenie otca a ostatnej rodiny - z rozhovorov vyplynulo, že podpora či pomoc od najbližšej rodiny je pre matky vel'mi dôležitá, pričom ju často vnímajú ako nedostatočnú, najmä čo sa týka zapojenia sa do každodennej prípravy do školy. Anna vysvetluje, že od manžela sa jej nejakej pomoci dostáva, priala by si však, aby viac participoval na učení sa s dcérou: „že by som si strašne chcela dopriat jak sa povie chvílu pre seba, jeden deň nemysliet na školu, ... aby prišiel a s ňou sa učil. " Ťažkosti s dietatom zároveň považuje za zdroj manželskej krízy: „, a priznám sa, že asi máme už aj krízu... úplne nás to dieia odlúćilo ako partnerov. "Eva sa nemohla spolahnút ani na pomoc otca, u ktorého dcéra trávila len niekol'ko víkendov v roku, ani na vlastnú matku: „Lebo oni sa s ňou nemuseli učit, oni jej všeličo dovolili, u nich bolo super.“ Naopak Beáta s Dianou pozitívne hodnotia podporu zo strany rodiny: ,z rodiny mám dobré pochopenie, či mojej, či manželovej... moja mama si dokonca aj prečítala knižku o tom..., " hovorí Diana.

Nedostatok podpory zo strany spoločnosti - na rozdiel od hodnotenia podpory od rodiny, matky zhodne uvádzajú nepochopenie zo strany spoločnosti. Anna spomína na kolegyne (,Je mi do plaču, vôbec nevedia, aký život žijem. “) i na rodičov spolužiakov. Najväčšie zastúpenie v pocite nedostatku podpory mala oblast školstva a hlavne nepochopenie zo strany učitelov. Matky takmer zhodne považujú za dôležitý zdroj nepochopenia absenciu podobných skúseností (, Ked' to nezažiješ, v podstate to ani nejde pochopit."). 


\section{Intervenčný program ako ,bod zlomu“":}

Téma intervenčného programu sa vyskytovala v rozhovoroch troch matiek. Anna ako jediná nemala s takouto intervenciou žiadne skúsenosti. Tri ženy absolvovali v rôznych časových obdobiach program realizovaný organizáciou Detský fond SR Rodina s hyperaktívnym dietatom (bližšie opísaný v úvode), ktorý v rozhovoroch nazývali skrátene „Skupina $A D H D$ “. Matky hodnotia program velmi pozitívne, Diana používa slovné spojenie ,bod zlomu“. V rozprávaní o tejto téme boli identifikované štyri subtémy, ktoré boli zároveň sumarizáciou toho, čo považovali matky za najdôležitejšie v programe: praktické informácie, uvedomenie si potreby zmeny prístupu, aplikácia nových postupov do výchovy a sociálna podpora $\mathrm{v}$ terapeutickej skupine. Participantky vyzdvihovali v prvom rade praktické informácie v oblasti riešenia výchovných situácií, s ktorými si nevedeli rady.

Uvedomenie si potreby zmeny prístupu - matky primárne od programu očakávali zameranie na prácu s diełatom, aby sa naučili ako sa majú správat, a tým sa zbavili problémov. Postupne však začali chápat nutnosł zmeny postoja. Beáta spätne hodnotí ako obzvlášt užitočnú radu ohladom postoja k domácim úlohám: „že to niekedy nie je až také dôležité, rodinná pohoda je niekedy dôležitejšia... " Eva hovorí o zmene vnímania dcérinho správania: „Naučil ma na ňu ináč pozerat, a teda ináč s ňou komunikovat..., ale ten proces trvá roky. “

Aplikácia nových postupov do výchovy podla vyjadrení matiek neprebiehala vždy jednoducho. Beáta spomína: „...tak ja som musela tiež zmenit svoje zvyky, svoje správanie... takže ja som musela tiež na sebe zapracovat."

Sociálna podpora $v$ terapeutickej skupine bola vnímaná ako najväčšie pozitívum programu. Matky si cenili otvorenú atmosféru, možnosit podelit sa o problémy s ostatnými rodičmi, spoločné hladanie riešení problémov a povzbudenie, ktoré sa im tu dostávalo. Eva konštatuje: „Bola to strašná pomoc. Konečne som zistila, že majú aj druhí problémy, že dokonca niektorí majú horšie ako ja, sa mi zdali, hej?"

\section{Potreby a očakávania matiek:}

V súvislosti s témou podpory a pomoci sme sa respondentiek pýtali, aká je ich predstava, čo by im najviac pomohlo, a aké majú očakávania od odborníkov. V ich apeloch najvýraznejšie rezonovala potreba väčšej spolupráce zo strany školy, matky vyjadrili tiež potrebu asistenta v škole, športových krúžkov a osvety o ADHD.

Spolupráca školy bola spoločnou požiadavkou všetkých štyroch matiek, pričom pravdepodobne vyplýva z negatívnych skúseností. Diana spomína: „Jednoznačne pomoc od školy, od učitelov, ktorínechceli akceptovat', že môj syn nie je nevychovaný, ale má naozaj poruchu... Naše školstvo vôbec nie je pripravené na prácu s takýmito detmi. “

Asistent učitela je vnímaný ako významná forma pomoci pre žiaka s ADHD. Napriek snahe získat asistenta sa matky stretávali s nepochopením. Diana spomína: 
„Samozrejme, že ma v škole vysmiali, že na to nemá nárok a ak by mal, tak na to škola nemá peniaze."

Športové krúžky - participantky si uvedomujú, že hyperaktívne deti potrebujú dostatok pohybu, a radi by detom dopriali aktivity s trénermi, ktorí by nekládli dôraz na vrcholové výkony, ale skôr na odreagovanie. Diana priznáva: „....syna vyhodili $z$ plávania, lebo nechcel robit presne to, čo ostatní. A pritom on tak potreboval pohyb. “

Osveta o ADHD - Matky detí s ADHD očakávajú od odborníkov šírenie osvety: „Stále treba robit osvetu, širit informácie medzi ludí, vrátane učitelov, lekárov, rodičov, “ hovorí Diana. Beáta uvádza v tejto súvislosti tragický príbeh: „,sestra sa s kolegami rozprávala o knižke o ADHD a jeden z nich si ju kúpil a prečítal. Neskôr povedal, že vdaka knižke konečne pochopil syna. Žial neskoro, jeho syn sa pred niekolkými rokmi ako 19-ročný obesil."

c) Materská reflexia skúseností s ADHD

V závere rozhovoru sme matky požiadali o odpoved’ na otázku: „Čo Vám prinieslo to, že máte hyperaktívne dieta?“. Analýza ich reflexie zachytila dve hlavné témy: Negatívne hodnotenie života a Pozitívne aspekty ADHD (tabul'ka 4).

\section{Negatívne hodnotenie života:}

V reakcii na vyššie uvedenú otázku každá z matiek spontánne zareagovala vymenovávaním negatív. V niektorých prípadoch zazneli slová ako „starosti“, „trápenie“ či „,zničený život“. Z výpovedí sme zosumarizovali subtémy Prečo ja? a Sklamanie z rodičovstva, ktoré spolu úzko súvisia, preto ich opisujeme spoločne. Viaceré matky sa zhodujú, že otázka „prečo ja?“" sa im niekolkokrát

Témy a subtémy tematickej oblasti Materská reflexia skúseností s ADHD

\begin{tabular}{|c|c|c|c|c|c|}
\hline \multirow{2}{*}{ Témy } & \multirow{2}{*}{ Subtémy } & \multicolumn{4}{|c|}{ Participantky - matky } \\
\hline & & Anna & Beáta & Diana & Eva \\
\hline $\begin{array}{c}\text { Negatívne } \\
\text { hodnotenie života }\end{array}$ & $\begin{array}{l}\text { „Prečo ja?“" } \\
\text { Sklamanie z rodičovstva }\end{array}$ & $*$ & $*$ & * & $*$ \\
\hline $\begin{array}{l}\text { Pozitívne aspekty } \\
\text { ADHD }\end{array}$ & $\begin{array}{l}\text { Akceptácia dietata s ADHD } \\
\text { Bližší vztah s dietałom } \\
\text { Zmena hodnotového systému } \\
\text { Práca na sebe - Osobnostný rast }\end{array}$ & $\begin{array}{l}* \\
* \\
*\end{array}$ & * & $\begin{array}{l}* \\
* \\
* \\
*\end{array}$ & * \\
\hline
\end{tabular}


premietla v hlave. Diana priznáva: „Pýtala som sa-Prečo práve ja musím mat takéto dieta? Č́m som si to zaslúžila? "Matky tiež naznačovali čiastočné sklamanie $\mathrm{z}$ rodičovstva. Zo všetkých rozhovorov sa dalo vycítie, že mali o rodičovstve a výchove dietata iné predstavy. Eva si spätne uvedomuje svoj podiel viny na nie vel'mi dobrom vzlahu s dcérou.

\section{Pozitívne aspekty ADHD:}

Pri premýšlaní o pozitívnych aspektoch participantky potrebovali viac času, výsledkom však boli väčšinou hlbšie a zaujímavejšie myšlienky. Uvedomenie si pozitív vyvolávalo nečakane silné emócie. Vynorenými subtémami sú akceptácia dietata s ADHD, bližší vztah s dietatom, zmena hodnotového systému a práca na sebe - osobnostný rast.

Akceptácia dietaía s ADHD - prvým pozitívom, ktoré matky vyzdvihli, bolo akceptovanie dietata vd’aka zmene postoja. Diana spomína: „Postupne som sa naučila rešpektovai človeka s iným chápaním sveta ako je ten môj... “

Bližši vzíah s dietatom - dalším pozitívom, ktoré zhodne uviedli Diana s Annou, je pocit prehíbenia vztahu s dietatom. Anna konštatuje: „Si s tým dietatom viac spätá. Proste, prě̌ívate spoločne aj intenzívnejšie plač, radost', všetko... “"

Zmena hodnotového systému - matky konštatujú zmenu vo vnímaní toho, čo je skutočne hodnotné. Anna hovorí o získaní empatického postoja k hendikepovaným lud’om, ako aj nové uvedomenie si hodnoty vol’ného času.

Práca na sebe - osobnostný rast - z výpovedí je zrejmé, že matky na sebe museli tvrdo pracovat. V tejto súvislosti spomínajú získané zručnosti ako trpezlivosé, sebaprijatie, schopnosî robit kompromisy, priznat si chybu a pod. Matky mladších detí hovorili najmä o trpezlivosti a snahe zmenit prístup k dietatu. Matky so staršími detmi si pozitívnu zmenu svojej osobnosti jasne uvedomujú a oceňujú. Diana priznáva: „Mňa to velmi posilnilo psychicky a možno keby syn ADHD nemal, bola by som dnes úplne iný človek. "

\section{Diskusia}

Cielom tejto práce bolo získat hlbší vhlad do skúseností matiek s výchovou detí s ADHD a lepšie im porozumiet. Na dosiahnutie ciela a zodpovedanie výskumnej otázky sme použili metódu interpretatívnej fenomenologickej analýzy, ktorá sa osvedčila ako vhodná metóda pre skúmanie daného fenoménu. Výsledkom analýzy štyroch rozhovorov bolo sformulovanie troch hlavných tematických oblastí, zahŕňajúcich desat hlavných tém so subtémami.

Prvá tematická oblasê s názvom Špecifiká materstva s dietatom s ADHD zahŕňa najdôležitejšie témy v oblasti výchovy z pohladu matiek hyperaktívneho dietata. 
Približuje životné skúsenosti matiek pred diagnostikou diełała a tiež postoj, ktorý zaujali po nej. V súvislosti so zaznamenaním prvých príznakov matky vo výskume potvrdzujú, že už od narodenia diełała si všímali jeho „iné“ správanie. Vyjadrenia o nepokojnom dietati, problémoch so spánkom, nadmernej plačlivosti či motorickej neobratnosti zodpovedajú prvotným príznakom ADHD v útlom veku. Po stanovení diagnózy ADHD niektoré matky hovorili o pocite úlavy, pretože dovtedy mali pochybnosti o vlastných rodičovských kompetenciách. Podobné pocity sa potvrdili aj u rodičov v kvalitatívnom výskume, ktorý realizovali O. Moen, M. Hall-Lord a B. Hedelin (2011). Pretrvávajúce problémy s prijatím diagnózy opätovne verbalizovala jediná matka (Anna). Neprijatie diagnózy a nadmerné obhajovanie diefata sa často vyskytuje v tzv. rodinách ovládaných poruchou $A D H D$, ktoré vo svojej typológii opisujú J. Kendall a K. Shelton (2003).

Výsledky analýzy naznačujú, že školské problémy matky vnímajú ako najvýznamnejší zdroj zátaže, čo potvrdzuje aj obsažnoste vyjadrení na túto tému. Úsilie, vynaložené na zvládanie školských tažkostí, matky neraz hodnotia ako neefektívne. Ich pocity sú v súlade so zisteniami R. Gwernan-Jonesovej et al. (2015), že dobré vztahy medzi rodičmi detí s ADHD a učitel'mi sú považované za výnimku a matky sú neraz konfrontované s kritikou a obviňovaním z neschopnosti vychovávat. Uvádzajú tiež pretrvávajúcu tendenciu učitelov polemizovat o diagnóze dietata. N. E. Hill a L. O. Taylor (2004) potvrdzujú, že v prípade kvalitnej spolupráce so školou sa významne zvyšuje sociálny kapitál rodičov i efektivita prípravy do školy. V tejto súvislosti je nutné venovat zvýšenú pozornosê vzájomným vztahom medzi rodičmi a pedagógmi, ako aj konkrétnym problémom $\mathrm{v}$ školskom prostredí.

Dôležitým zistením je tendencia zmenit dietału školu ako východisko z nepriaznivej situácie. Domnievame sa, že dôležitou výzvou pre psychológov je osveta medzi pedagógmi a d’alšími osobami, ktoré pracujú s detmi s ADHD (napr. vychovávatelia, tréneri). Za obzvlášê vyčerpávajúce považujú matky každodenné aktivity, spojené s prípravou do školy, ktorú komplikuje deficit motivácie a pozornosti, časový stres, ale aj negatívna odozva zo školy. Ukazuje sa, že otcovia sa do týchto činností zapájajú podstatne menej, nižšia angažovanost̉ bola potvrdená vo viacerých výskumoch (Moen et al.; 2011, Fabiano, 2007). Na základe rozsiahleho rešeršu literatúry dospel J.H. Pleck (podla Joseph, Linley, 2006) k záveru, že aktívna účast otca na výchove má priaznivý vplyv na manželskú spokojnost', ale aj správanie a školské výsledky diełała.

Z vyjadrení matiek bolo zjavné, že cítili nedostatok sociálnej podpory zo strany spoločnosti. Stretávali sa s nepochopením najmä zo strany vzdialenejšej rodiny, učitelov, spolužiakov a ich rodičov. Súčasne vyjadrili nespokojnost s kvalitou odbornej pomoci a odporúčaní, ale aj účinkami farmakoterapie. Uvedené je v zhode so zisteniami G. Langeho et al. (2005), ktoré poukázali na nespokojnost' s rodinnou a odbornou podporou rodičov detí s ADHD. Na druhej strane matky, ktoré 
absolvovali intervenčný program pre rodiny s detmi, ho spätne hodnotia ako velmi účinnú formu pomoci. Ocenili najmä praktické rady k výchove a možnosê navštevovat podpornú skupinu. Ich skúsenosti sú v súlade s výskumami, ktoré ukazujú, že sociálna podpora je vel’mi prospešná pre ludí załažených nadmerným stresom (Williams, Galliher, 2006), ku ktorým jednoznačne patria rodičia vychovávajúci deti s ADHD (Treacy, Tripp, Baird, 2005). Psychosociálne formy intervencie môžu zlepšit emocionálne a spoločenské fungovanie rodičov a súčasne eliminovat rodičovský stres (napr. Chronis, et al., 2004; Sonuga-Barke et al., 2010), či prispię k zmene rodičovského štýlu (Treacy, et al., 2005). I ked' naša vzorka nie je postačujúca na zovšeobecnenie záverov o účinnosti spomenutého programu pre rodiny s ADHD, zistenia prispievajú $\mathrm{k}$ diskusii o potrebe realizovat podobné programy na Slovensku vo väčšej miere.

Vo vzlahu k dielatu participantky prechádzali procesom od jeho nepochopenia a neprijatia po akceptáciu a zmenu postoja $\mathrm{k}$ jeho prejavom, pričom často pocitovali ambivalentné emócie. Primárne uvádzané kritickejšie postoje môžu nepriaznivo vplývat na vzájomnú interakciu medzi matkou a dietatom (Seipp, Johnston, 2005), súčasne môžu vypovedat o autoritatívnom štýle rodičovstva, ktorý je častejšie pozorovaný u matiek detí s ADHD (Yousefia, Soltani, Abdolahian, 2011; Bhide et al., 2017).

Na záver boli matky požiadané o krátku reflexiu toho, čo im priniesol život s dietatom s ADHD. V tejto súvislosti všetky spontánne uvádzali najmä negatívne aspekty, pričom rozprávali o trápení, starostiach a sklamaní z rodičovstva, či dokonca o „zničenom živote“. Zahraničné štúdie potvrdzujú tendenciu rodičov zdôrazňovat tažkosti a negatívne prežívanie v rodinách s diełałom s ADHD. Väčšina rodičov vníma každodenné zvládanie detí s ADHD ako nadmernú zátaž a vyjadruje nespokojnosê $\mathrm{s}$ rodičovstvom, či negatívne hodnotenie vlastných rodičovských kompetencií (Harrison, Sofronoff, 2002; Johnston, Mash, 2001). Len malá výskumná pozornosî bola venovaná pozitívnym účinkom na rodičov. $V$ našom výskume matky až po hlbšom zamyslení začali pomenovávat viacero pozitívnych skutočností, ktoré im skúsenost $\mathrm{s}$ výchovou diełata s ADHD priniesla. Rovnako ako v kvalitatívnom výskume E. S. Segalovej (2001), matky uvádzali pocity väššej zrelosti a empatie s inými lud’mi s podobnými problémami. Niektoré opisujú väčšiu odhodlanost a schopnost bojovat, aby pomohli svojmu dietatu. Najmä matky starších detí verbalizovali a kladne hodnotili výraznú osobnostnú zmenu ako dôsledok akceptácie a prekonania náročných situácií s diefałom. Ako potenciálny zdroj rastu okrem sociálnej podpory identifikovali Finzi-Dottan, et al., 2011 aj emocionálnu inteligenciu, ktorá v ich výskume prispievala $\mathrm{k}$ osobnostnému rastu rodičov detí s ADHD a nie rodičov kontrolnej skupiny. Je možné, že emocionálne zvládanie je aktivované najmä pri nadmernej zátaži, zdrojom ktorej môže bye život s diełałom s ADHD. V týchto situáciách na problém zamerané zvládanie nemusí byt účinné. 
V našom výskume sme sa zamerali výlučne na rozhovory s matkami, preto nie je možná generalizácia na celú rodinu. Limitáciou práce je vyššia miera subjektivity, ktorá je typická pre kvalitatívny výskum a ovplyvňuje celý proces analýzy. Obmedzenie sme sa pokúsili zmiernit prostredníctvom priamych citácií účastníčok výskumu, ktoré dopíňajú našu interpretáciu. Druhým krokom k vyššej objektivite výskumu bolo využitie d’alších výskumníkov pri vytváraní interpretačných kategórií. Nedostatkom je aj malý počet participantiek, ktoré nemôžu reprezentovat celú populáciu matiek detí s ADHD. Vychádzali sme pri tom z odporúčaní J. Smitha et al. (2009), ktorí pre účely interpretatívnej fenomenologickej analýzy hovoria o ideálnom počte $3-6$ respondentov, pričom sme uprednostnili bohatost a hĺbku dát pred vyšším počtom účastníkov.

\section{Záver}

V našej práci sme sa venovali skúsenostiam matiek s výchovou detí s ADHD. Primárnym cielom bolo poskytnút náhlad do života rodín s takýmto dietatom, ktoré sú vystavené nadmernému stresu a každodenným zátažovým situáciám a zároveň často bojujú s nedostatkom pochopenia a sociálnej podpory. Ukázalo sa, že matky napriek vnímaniu negatívnych aspektov života spojeného s touto poruchou dokážu nájste viacero pozitív, ktoré, ako sa zdá, prispievajú k osobnostnému rastu matiek.

Klúčovým prínosom práce je pomenovanie a analýza problémov a situácií, s ktorými denne zápasia matky detí s ADHD, čo môže pomôct odborníkom, ktorí pracujú s rodinami s podobnými problémami, lepšie porozumiet ich prežívaniu a poskytnút im pomoc. Naše zistenia môžu prispiet k d'alšej diskusii o potrebe realizovat intervenčné programy pre rodiny s detmi s ADHD, ktorých je v našich podmienkach nedostatok, ako aj o potrebe šírenia osvety o ADHD medzi učitel'mi a vychovávatelmi, ktorí s detmi každodenne pracujú.

Do budúcna navrhujeme zamerat sa na percepciu opísaných problémov učitelmi, ako aj na overenie efektivity jednotlivých intervencií pre deti a rodiny. Pozitívne hodnotenie účinkov skupinového programu môže byê podnetom pre vytváranie podobných projektov, ako aj zvýšenie ich dostupnosti pre rodičov detí s ADHD z rozličných geografických oblastí.

\section{LITERATÚRA}

BHIDE, S. - SCIBERRAS, E. - ANDERSON, V. - HAZZEL, P. - NICHOLSON, J. M.2017. Association Between Parenting Style and Socio-Emotional and Academic Functioning in Children With and Without ADHD: An 18-Month Longitudinal Study. Journal of Developmental a Behavioral Pediatrics, vol. 38, no. 6, p. 369-377. 
CORCORAN, J. - SCHILDT, B. - HOCHBRUECKNER, R. - ABELL, J. 2017. Parents of Children with Attention Deficit/Hyperactivity Disorder: A Meta-Synthesis, Part II. Child and Adolescent Social Work Journal, vol. 34, no. 4, p. 337-348.

CRAIG, F. - OPERTO, F. F. - DE GIACOMO, A. - MARGARI, L. - FROLLI, A. - CONSON, M. - IVAGNES, S. - MONACO, M. - MARGARI, F. 2016. Parenting stress among parents of children with Neurodevelopmental Disorders. Psychiatry Research, vol. 242, Aug 30, p. 121-129.

FABIANO, G. 2007. Father participation in behavioral parent training for ADHD: Review and recommendations for increasing inclusion and engagement. Journal of Family Psychology, vol. 21 , no. 4 , p. 683-693.

FINZI-DOTTAN, R. - TRIWITZ, S.Y. - GOLUBCHIK, P. 2011. Predictors of stress-related growth in parents of children with ADHD. Research in Developmental Disabilities, vol. 32, no. 2, p. 510-519.

GWERNAN-JONES, R. - MOORE, D. - GARSIDE, R. - RICHARDSON, M. - THOMPSON-COON, J. - ROGERS, M. - COOPER, P. - STEIN, K. - FORD, T. 2015. ADHD, parent perspectives and parent-teacher relationships: grounds for conflict. British Journal of Special Education, vol. 42, no. 3, p. 279-300.

HARRISON, C. - SOFRONOFF, K. 2002. ADHD and parental psychological distress: Role of demographics, child behavioral characteristics, and parental cognitions. Journal of the American Academy of Child and Adolescent Psychiatry, vol. 41, no. 6, p. 703-711.

HILL, N. E. - TAYLOR, L. C. 2004. Parental school involvement and children's academic achievement: Pragmatic and issues. Current Directions in Psychological Science, vol. 13, no. 161-164.

HLAVÁČOVÁ, Z. 2015. Bariéry pri aplikácii všeobecných reedukačných zásad vo výchove dietata s ADHD. Psychológia a patopsychológia dietata, č. 9, s. 6-15.

CHRONIS, A. M. - CHACKO, A. - FABIANO, G. A. - WYMBS, B. T. - PELHAM, W. E. 2004. Enhancements to the Behavioral Parent Training Paradigm for Families of Children With ADHD: Review and Future Directions. Clinical Child and Family Psychology Review, vol. 7, no. 1, p. 1-27.

JOHNSTON, C. - MASH, E. 2001. Families of children with attention-deficit/hyperactivity disorder: Review and recommendations for future research. Clinical Child and Family Psychology Review, vol. 4, no. 3, p.183-207.

JOSEPH, S. - LINLEY, P. A. 2006. Growth following adversity: Theoretical perspectives and implications for clinical practice. Clinical Psychology Review, vol. 26, p. 1041/1053.

KENDALL, J. - LEO, M. C. - PERRIN, N. - HATTON, D. 2005. Modeling ADHD Child and Family Relationships. Western Journal of Nursing Research, vol. 27, no. 4, p. 500-518.

KENDALL, J. - SHELTON, K. 2003. A Typology of Management Styles in Families with Children with ADHD. Journal of Family Nursing, vol. 9, no. 3, p. 257-280.

KOSTÍNKOVÁ, J. - ČERMÁK, I. 2003. Interpretativní fenomenologická analýza. In: Řiháček, T., Čermák, I., Hytych, R.: Kvalitativní analýza textů-čtyři přístupy. 1. vyd. Brno: Masarykova univerzita, 2013, s. 9-43. ISBN 978-80-210-6382-2.

KVAŠNÁ, L. 2011. Interpersonálne vztahy u detí v ranom a strednom školskom veku s diagnózou ADHD. In: T. Galis, F. Horn, E. Klčovanská, J. Štefanec (Eds.): Zborník z vedeckej konferencie organizovanej Radou pre mládež a univerzity KBS v Badíne 5. - 6. septembra 2011 Univerzita - miesto stretnutia a konfrontácie viery a rozumu. 1. vyd. Badín: Rada pre mládež a univerzity KBS, s. 121-160. ISBN 978-80-970613-3-3.

LANGE, G. - SHERRIN, D. - CARR, A. - DOOLEY, B. -BARTON, V. - MARSHALL, D. - MULLIGAN, A. - LAWLOR, M. - BELTON, M. - DOYLE, M. 2005. Family factors associated with ADHD and emotional disorders in children. Journal of Family Therapy, vol. 27, no. 1, p. 76-96. 
LAVER-BRADBURY, C. 2013. ADHD in children: An overview of treatment. Nurse Prescribing, vol. 11, no. 12, p. 597-601.

MINAŘÍKOVÁ, L. 2010. Dítě s ADHD v mateřské škole [online]. Metodický portál: Články [citované 02.04.2018]. Dostupné na: https://clanky.rvp.cz/clanek/c/s/7993/DITE-S-ADHDVMATERSKE-SKOLE.html

MOEN, O. - HALL-LORD, M. - HEDELIN, B. 2011. Contending and adapting everyday: Norwegian parents' lived experience of having a child with ADHD. Journal of Family Nursing, vol.17, no. 4, p. 441-462.

POLANCZYK, G. - WILLCUTT, E. - SALUM, G. - KIELING, C. - ROHDE, L. 2014. ADHD prevalence estimates across three decades: An updated systematic review and meta-regression analysis. International Journal of Epidemiology, vol. 43, no. 2, p. 434-442.

SEGAL, E. S. 2001. Learned mothering: Raising a child with ADHD. Child and Adolescent Social Work Journal, vol. 18, no. 4, p. 263-279.

SEIPP, C. - JOHNSTON, C. 2005. Mother-son interactions in families of boys with ADHD with and without oppositional behavior. Journal of Abnormal Child Psychology, vol. 33 no. 1, p. 87-98.

SMITH, J. - EATOUGH, M. 2011. Interpretative Phenomenological Analysis, Analysing Qualitative Data in Psychology [online]. London, SAGE, s. 35-50. [citované 02.04.2018]. Dostupné na: http://methods.sagepub.com/book/analysing-qualitative-data-in-psychology

SMITH, J. - FLOWERS, P. - LARKIN, M. 2009. Interpretative phenomenological analysis: theory, method and research. Thousands Oaks: Sage. ISBN 9781412908344.

SMITH, J. - OSBORN, M. 2003. Interpretative phenomenological analysis [online]. Qualitative Psychology: A Practical Guide to Research Methods, p. 53-80. [citované 01.04.2018]. Dostupné na: http://med-fom-familymed-research.sites.olt.ubc.ca/files/2012/03/IPA_Smith_Osborne21632.pdf

SONUGA-BARKE, E. J. - HALPERIN, J. M. 2010. Developmental phenotypes and causal pathways in attention deficit/hyperactivity disorder: potential targets for early intervention? Journal of Child Psychology and Psychiatry, vol. 51, no. 4, p. 368-389.

ŠTEPITA, M. 2014. Hyperaktívne deti [online]. [citované 18.11.2017]. Dostupné na: https://www. dfsr.sk/16/

TREACY, L. - TRIPP, G. - BAIRD, A. 2005. Parent Stress Management Training for AttentionDeficit/Hyperactivity Disorder. Behavior Therapy, vol. 36, no. 33, p. 223-233.

UHLÍKOVÁ, P. - PTÁČEK, R. - PTÁČKOVÁ, H. 2014. Diagnostika a léčba ADHD v průběhu Života. Postgraduální medicína, roč. 16, č. 6, s. 604-12.

WILLIAMS, K. L. - GALLIHER, R.V. 2006. Predicting depression and self-esteem from social connectedness, support, and competence. Journal of Social and Clinical Psychology, vol. 25, no. 8, p. 855-874.

YOUSEFIA, S. H. - SOLTANI, F. A. - ABDOLAHIAN, E. 2011. Parenting stress and parenting styles in mothers of ADHD with mothers of normal children. Procedia - Social and Behavioral Sciences, vol. 30, no. 1, p. 1666-1671.

Súhrn: Cielom štúdie je poskytnút hlbší vhlad do skúseností matiek, ktoré vychovávajú dieta s ADHD. V rámci výskumu boli realizované pološtrukturované híbkové rozhovory so štyrmi matkami. Následne bola aplikovaná interpretatívna fenomenologická analýza, na základe ktorej boli identifikované tri základné tematické oblasti: Špecifiká materstva diełała s ADHD, Charakteristika pomoci a podpory, Materská reflexia skúseností s ADHD. Výsledky analýzy preukázali, že pri výchove dietała s ADHD sa matky stretávali s nepochopením a neakceptáciou zo strany školy a za jediné východisko považovali jej zmenu. Matky pozitívne hodnotili využitie intervenčného 
programu pre rodiny s ADHD a napriek mnohým tažkostiam pri výchove dokázali vnímat viacero pozitívnych aspektov, ktoré prispievajú k ich osobnostnému rastu.

Klúčové slová: materstvo, ADHD, intervenčný program, osobnostný rast, fenomenologická analýza

Mgr. Monika Búranová ukončila v akademickom roku 2017/2018 štúdium psychológie na Filozofickej fakulte Trnavskej univerzity v Trnave. V diplomovej práci sa venovala problematike rodín, v ktorých vyrastá dieta s ADHD.

Mgr. Jana Vindišová, PhD. je odbornou asistentkou Katedry psychológie Filozofickej fakulty Trnavskej univerzity v Trnave. Výskumne sa zameriava na oblast' psychológie zdravia a psychológie detí a adolescentov. Pracuje tiež ako psychologička v súkromnom centre špeciálno-pedagogického poradenstva v Novej Dubnici. 